\title{
Serum Calcium Levels In Type 2 Diabetes Mellitus
}

\author{
Kanchana. $\mathrm{N}^{1}$, Saikumar. $\mathrm{P}^{2}$ \\ ${ }^{1}$-Department of physiology / Sree Balaji Medical College, Bharath University, Chennai India / \\ Second year Physiology PG \\ ${ }^{2}$ - Department of physiology / Sree Balaji Medical College, Bharath University, Chennai India / \\ Professor and HOD
}

\begin{abstract}
:
Introduction: Hyperglycemia in Diabetes Mellitus is known to have its effect on almost all body system through alterations in structural and biochemical changes in tissues.From this study it is hypothesized that alteration in calcium flux may adversely affect the insulin secretion as it is a calcium dependent process.

Aim And Objectives: This study was done to estimate the serum calcium levels in type 2 Diabetes mellitus.

Objectives:

1.Estimation of blood glucose levels in all subjects.

2.Estimation of serum calcium levels in diabetes and non-diabetes.

3.Compare the serum calcium levels in diabetes and non-diabetes.

Materials and methods:

Case control study.

Study Design: Diabetes subjects (cases) $n=50$

Age and sex matched non diabetes (controls) $n=50$

Plasma glucose levels was estimated by GOD-POD method.Serum calcium level was estimated by calcium Arsenazo method for all subjects at central lab of SBMCH,Chennai.

Results And Conclusion: Results were analyzed using anova single factor.f statistical was greater than $f$ critical value.

A negative correlation was observed between serum calcium levels and plasma blood glucose levels. Also the $p$ value was found to be less than 0.05 which confirmed that correlation was statistically significant.
\end{abstract}

Key Words: Diabetes mellitus, Hyperglycemia,Hypocalcemia,Plasma glucose, Serum calcium,

\section{Introduction}

Diabetes mellitus is a metabolic disease that is very common in India. Diabetes mellitus is known to have its effect on almost all body systems causing various structural and biochemical changes. From this study it is hypothesized that alterations in calcium flux may adversely affect the insulin secretion as insulin secretion is a calcium mediated process.

There are various risk factors for diabetes,obesity being one of the commonest [1]. Weight control is difficult to maintain on a long term basis. Hence there arises a need for easily modifiable risk factors.

\section{Materials And Methods}

Ours was a case control study where in data was collected from 128 subjects but only 42 non Diabetic and 48 diabetic volunteered to give blood samples for the laboratory investigations. All investigations were carried out at the central lab of Sree Balaji Medical College,Chennai.

Plasma blood glucose level was estimated by GOD-POD method (Reference range-70-110 $\mathrm{mg} / \mathrm{dl}$ ). Serum Calcium by Arsenazo(Reference range-8.9-10.3mg/dl) was estimated at the central lab.

All the subjects were given a questionnaire were in they were asked to fill details regarding age, body weight, physical activity,smoking status, alcohol usage,drug intake,history of hypertension, asthma,duration of diabetes, symptoms of hypocalcaemia such as myalgia, arthralgia, pins and needles sensation, weakness, paresthesias.

Hypertensive, asthmatics,subjects suffering from osteoporosis,osteomalacia,end stage renal failure, and pregnancy where excluded from the study. 


\section{Statistical Analysis}

Table-1: Anova analysis for diabetes and non-diabetes-

\begin{tabular}{|c|c|c|c|c|c|c|}
\hline Anova: Single Factor & & & & & & \\
\hline \multicolumn{7}{|l|}{ SUMMARY } \\
\hline Groups & Count & Sum & Average & Variance & & \\
\hline PLASMA BLOOD GLUCOSE LEVELS (mg/dl) & 90 & 12325 & 136.9444444 & 3727.378901 & & \\
\hline SERUM CALCIUM LEVELS (mg/dl) & 90 & 851 & 9.455555556 & 0.388339576 & & \\
\hline \multicolumn{7}{|l|}{ ANOVA } \\
\hline Source of Variation & SS & $d f$ & MS & $F$ & P-value & F crit \\
\hline Between Groups & 731403.7556 & 1 & 731403.7556 & 392.4084892 & $6.96761 \mathrm{E}-47$ & 3.894232131 \\
\hline Within Groups & 331771.2844 & 178 & 1863.88362 & & & \\
\hline Total & 1063175.04 & 179 & & & & \\
\hline
\end{tabular}

Table-2: Correlation between plasma glucose levels and serum calcium levels:

\begin{tabular}{|l|r|r|}
\hline & PLASMA BLOOD GLUCOSE LEVELS $(\mathrm{mg} / \mathrm{dl})$ & SERUM CALCIUM LEVELS $(\mathrm{mg} / \mathrm{dl})$ \\
\hline PLASMA BLOOD GLUCOSE LEVELS (mg/dl) & 1 & 1 \\
\hline SERUM CALCIUM LEVELS (mg/dl) & -0.284110641 & 1 \\
\hline
\end{tabular}

\section{Results And Discussion}

Results were analyzed using anova single factor.f statistical value was found to be greater than $\mathrm{f}$ critical value.p value was less than 0.05 which confirmed that the association was statistically significant. as shown in Table-1.

A negative correlation was observed between plasma blood glucose and serum calcium levels that is increased plasma glucose levels was associated with decreased serum calcium levels as shown in Table- 2 .

\section{Discussion}

Diabetes is a very common disease in India with the number of diabetes cases is increasing every year at an alarming rate.There arises a need for implementing cost effective and effective measures to prevent as well as control the disease.

Insulin secretion is a calcium dependent process. When blood glucose levels increase the glucose is transported inside with help of GLUT-4 transporters. This glucose is converted to glucose-6-phosphate with aid of glucokinase. This is further oxidized to yield increased ATP which causes closure of potassium channels and hence depolarization of the cell membrane. Depolarizationcauses increase of calcium flux through calcium channels which causes docking of vesicles containing insulin to fuse with the cell membrane.Insulin is then secreted by exocytosis.

Calcium is important for insulin mediated intracellular processes in insulin responsive tissues such as adipose tissue and skeletal muscle with a very narrow range necessary for optimal insulin action. Further calcium is necessary for insulin receptor phosphorylation and proper signal transduction and thus optimal GLUT-4 transporter activity.

- Alterations in calcium flux can have adverse effects on insulin secretion, acalcium-dependent process.Calcium repletion alone normalized glucose tolerance and insulin secretion invitamin Ddepleted rats. $[13,14]$

- In people without diabetes, hypocalcaemia is associated with impairment of insulin release

- In diabetes patients, an oral calcium load augments glucose-induced insulinsecretion [10].

- Patients with resistance to $1,25-\mathrm{OHD}$ were found to have abnormal insulinsecretion only if they were hypocalcaemia[4, 5, 6, 13, 14]

- Changes in Calcium in primary insulin target tissues contributes to alterations ininsulin action

- Impairment of insulin receptor phosphorylation, a calcium-dependent processleads to impaired insulin signal transduction and decreased glucose transporter-4 activity

- Changes in calcium modulate adipocyte metabolism, which may promotetriglyceride accumulation via increased de novo lipogenesis and inability tosuppress insulin-mediated lipolysis leading to fat accumulation.

- Patients with type $2 \mathrm{DM}$ exhibit impaired cellular calcium homeostasis including defects in skeletal muscle, adipocytes, and liver. Changes in calcium may lead to cytokine-induced apoptosis. 


\section{Conclusion}

Thus it can be seen that the role of calcium in the etiopathogenesis of diabetes is multifactorial.If calcium is supplemented along with vitamin D to diabetes patients it can help in better glycemic control as well as prevent early onset of diabetes if supplemented in non-diabetes subjects.

\section{References}

[1]. Mokdad AH, Ford ES, Bowman BA, Dietz WH, Vinicor F, Bales VS, MarksJS 2003 Prevalence of obesity, diabetes, and obesityrelated health risk factors,2001. JAMA 289:76-79

[2]. HuFB, Manson JE, Stampfer MJ, Colditz G, Liu S, Solomon CG, WillettWC2001 Diet, lifestyle, and the risk of type 2 diabetes mellitus in women. N EnglJ Med 345:790-797

[3]. Benjamin SM, Valdez R, Geiss LS, Rolka DB, Narayan KM 2003 Estimatednumber of adults with prediabetes in the US in 2000: opportunities forprevention. Diabetes Care 26:645-649

[4]. Bischoff-Ferrari HA, Giovannucci E, Willett WC, Dietrich T, Dawson-Hughes B 2006 Estimation of optimal serum concentrations of 25-hydroxyvitaminD for multiple health outcomes. Am J Clin Nutr 84:18-28

[5]. Holick MF 2006 High prevalence of vitamin D inadequacy and implicationsfor health. Mayo Clin Proc 81:353-373

[6]. Mathieu C, Badenhoop K 2005 Vitamin D and type 1 diabetes mellitus: stateof the art. Trends Endocrinol Metab 16:261-266

[7]. Toma M, McAlister FA, Bialy L, Adams D, Vandermeer B, Armstrong PW2006 Transition from meeting abstract to full-length journal article for randomizedcontrolled trials. JAMA 295:1281-1287

[8]. Bloch CA, Clemons P, Sperling MA 1987 Puberty decreases insulin sensitivity.J Pediatr 110:481-487

[9]. Polonsky KS, Given BD, Hirsch L, Shapiro ET, Tillil H, Beebe C, GallowayJA, Frank BH, Karrison T, Van Cauter E 1988 Quantitative study of insulinsecretion and clearance in normal and obese subjects. J Clin Invest 81:435-441

[10]. DerSimonian R, Laird N 1986 Meta-analysis in clinical trials. Control ClinTrials 7:177-188

[11]. Weyer C, Bogardus C, Mott DM, Pratley RE 1999 The natural history ofinsulin secretory dysfunction and insulin resistance in the pathogenesis oftype 2 diabetes mellitus. J Clin Invest 104:787-794

[12]. Hu FB, Meigs JB, Li TY, Rifai N, Manson JE 2004 Inflammatory markers andrisk of developing type 2 diabetes in women. Diabetes 53:693-700

[13]. Bourlon PM, Billaudel B, Faure-Dussert A 1999 Influence of vitamin D3deficiency and 1,25 dihydroxyvitamin D3 on de novo insulin biosynthesis inthe islets of the rat endocrine pancreas. J Endocrinol 160:87-95

[14]. Zeitz U, Weber K, Soegiarto DW, Wolf E, Balling R, Erben RG 2003 Impairedinsulin secretory capacity in mice lacking a functional vitamin Dreceptor. FASEB J 17:509-511

[15]. Bland R, Markovic D, Hills CE, Hughes SV, Chan SL, Squires PE, HewisonM 2004 Expression of 25-hydroxyvitamin D3-1_hydroxylase in pancreaticislets. J Steroid Biochem Mol Biol 89-90:121-125 